\title{
Mapping the Contribution of Social Psychologists Toward Sus- tainable Development Goals (SDGs). Bibliometric and Content Analysis of Spanish Publications
}

\author{
Flor Sánchez ${ }^{1,4^{*}}$, Daniela De Filippo ${ }^{2,4}$, Amalio Blanco $^{1}$ and María Luisa Lascurain ${ }^{3,4}$ \\ 1 Department of Social Psychology. Universidad Autónoma de Madrid. flor.sanchez@uam.es, ama- \\ lio.blanco@uam.es \\ 2 IFS, Center for Human and Social Sciences (CCHS), Spanish National Research Council; daniela.defil- \\ ippo@cchs.csic.es \\ 3 Department of Library and Information Science. Universidad Carlos III de Madrid. mlascura@bib.uc3m.es \\ 4 Research Institute for Higher Education and Science (INAECU) \\ * Correspondence: flor.sanchez@uam.es
}

\begin{abstract}
This study analyses the papers published by Spanish social psychologists to determine whether they address topics related with the Sustainable Development Goals (SDGs). Publications by Spanish institutions indexed by the Web of Science in the thematic category of "Social Psychology" were subjected to bibliometric analysis. The publications were classified by their relationship with the SDGs using OSDG, an open-source labelling tool, and an in-depth content analysis was performed to validate the results. A corpus of 1632 papers published by Spanish institutions between 1980 and 2020 was identified. Thirty-four percent of the papers address matters related with the SDGs; $23 \%$ concern matters related with Goal 3 (good health and well-being), and $5 \%$, with Goal 5 (gender equality). Only $3 \%$ are interventions to modify behaviour or change social environments. Conclusions: The review of these papers allows detecting to what extent the research conducted in Social Psychology contributes to achieving the goals proposed in each of the SDGs. Also, the content analysis of this publications identifies several factors (cognitive, emotional, social or cultural) which should be investigated to improve knowledge on how to achieve the Sustainable Development Goals.
\end{abstract}

Keywords: Sustainable Development Goals; Social Psychology; scientific publications; Spain

\section{Introduction}

As we write this article, we are both witnessing and participating in society's scramble to cope with the effects of the COVID-19 epidemic, an event that has posed a worldwide threat to 21st-century societies' health and well-being. In response to the challenge, institutions have had to modify the procedures they use to take action, and citizens have had to change their ordinary ways of interacting with other people, in many cases adapting to novel working environments, and so on. These unexpected, unavoidable changes have caused high stress levels and revealed a deficit in the skills needed to manage the associated emotions, which in turn has caused a rise in the incidence of health problems, including mental health problems [1]. The epidemic has shaken our societies out of their complacency and exacerbated the uncertainty and agitation already caused by pre-existing social problems such as climate change, the energy crisis, social inequalities and migratory movements.

Many of the problems facing humanity, both now and before the pandemic, are addressed in the UN's 2030 Agenda [2], which is sets 17 Sustainable Development Goals (SDGs). To reach the targets included in each of the SDGs, scientists, like other social agents, are expected to do their part, each within the area of his or her discipline. 
Accordingly, social psychology could be reasonably expected to be doing something to address the challenge; reasonably, because psychology is essentially oriented toward achieving personal well-being. As early as 1970, in Psychology and the problems of society, the American Psychological Association (APA) declared that the discipline was supposed to study and research the problems society was grappling with at that time. This publication was preceded the year before by a landmark address by George Miller [3] as APA president, and what he said then remains just as applicable today: "The most urgent problems of our world today are the problems we have made for ourselves; they are human problems whose solutions will require us to change our behavior and our social institution" [3](p.1063). As a science dealing directly with behavioural and social processes, psychology, Miller said, should lead the way in the search for new and better personal and social scenarios and in the achievement of goals such as well-being, health, quality of life and maximum personal and group development, in all the realms of individual and social life, for it is this engagement with well-being that makes psychology legitimate as a science and as a profession. The conception of psychology as an instrument at the service of human well-being [3] and the definition of health as a state of well-being formulated in the founding act of the WHO in 1946, was later taken up by Keyes [4], Blanco and Díaz [5] to highlight the importance of circumstances and functioning within society: sense of belonging, quality of social relations, trust in others, trust in the society in which we live, etc. As for social psychology as a specific field of work, as the review by Blanco [6] shows, its usefulness in tackling social problems is unquestionable for authors as important as Elliot Aronson, who is convinced social psychology must be socially useful and "social psychologists can play a vital role in making the world a better place in which to live" [7] (p.13) Although the call for social relevance was the slogan of the so-called "crisis" of psychology, it is worth remembering that the assumption of scientific rationality (the capacity of the research task to respond to personal and social problems) was the framework within which authors of such theoretical ascendancy as Lev Vygotsky, George Herbert Mead and Kurt Lewin were situated. It is practice, Vygotsky [8] will say, which must mark the path of theory, which must dictate the construction of concepts and the formulation of theoretical arguments. All sciences, will say, have taken their first steps to respond to practical problems, [9] so that the contrast between theory and praxis, basic and applied research, is meaningless; they are only different moments of the same process. From the historiography of psychology, it has been stated that it was the social demand, the voices coming from the environment demanding help, which returned professionals to everyday reality [10]. With these considerations in mind, we have reviewed the contributions of social psychology research as expressed in scientific publications, with the ultimate goal of analysing the possible relationship between social psychology research and the topics and goals of the SDGs in the 2030 Agenda [2]. We might hypothesize, in view of how we have described the discipline's orientation, that at least part of the published research is probably related with Sustainable Development Goals focusing on health and well-being (SDG 3). In this context, a series of questions is posed to analyse the evolution of social psychology in Spain from the standpoint of its scientific results (in terms of publications in international scientific journals) and its relationship with the Sustainable Development Goals: What is the position of social psychology within the framework of general psychology? How has the discipline evolved over time? What kind of presence does Spanish social psychology have in the world? What are its main activity patterns? What topics does it address most frequently? Can any particular scientific activity oriented toward the study of SDGs be identified?

Objectives

- To find an answer to these questions, two general objectives are proposed:

- To assess the field of social psychology in Spain using bibliometric methods to ascertain the scientific production of the discipline, its main characteristics, its 
evolution and its contribution to the world as a whole and to the field of general psychology.

- To analyse the main topics addressed by social psychology in Spain and to establish whether there is an interest in topics related to the SDGs.

\section{Materials and Methods}

\subsection{Source of information}

The Web of Science core collection (WoS) from Clarivate Analytics was used to analyse scientific production in the field of social psychology. All three main databases -the Science Citation Index (SCI), the Social Science Citation Index (SSCI) and the Arts and Humanities Citation Index (AHCI)- were used.

\subsection{Data collection and search strategy}

Data were downloaded from WoS on September 2020. The search strategy was based on the WoS subject category (the database's thematic classification of indexed journals). All disciplines related to psychology were selected (11 WoS categories). Social psychology publications from Spain were found by filtering by discipline and country. No time limits were applied; all production up to the download date was collected.

\subsection{Information processing}

After the publications were downloaded, a relational database was constructed with the complete information on each publication.

\subsection{Development of bibliometric indicators.}

The following indicators were analysed for the final dataset:

1) Research patterns

- Yearly trend in scientific output in all psychology in the world and in Spain

- Yearly trend of publication in social psychology in the world and in Spain

- Distribution of publications by journal

2) Identification of areas and research specialties

- Co-occurrence of Web of Science categories to analyse relationships between disciplines

- Co-ocurrence of keywords to detect research specialties

3) Contribution to SDGs

Procedures for analysing the interest that social psychology has shown in issues related to SDGs:

- OSDG tool (www.osdg.ai) - an open-source tool which combines an ontology-based approach from previous projects and then matches to the fields of study from Microsoft Academic- was used to classify scientific outputs by assigning one or more SDGs to each document based on automated content analysis

-The title and abstract of all publications were reviewed manually to label the papers according to their relationship with the SDGs. The same procedure was used to classify the papers by type (empirical, theoretical or interventionist).

4) Visualization of the results

The information obtained is presented in tables and graphs. For visualization, tools such as Vosviewer were used to create thematic clusters. Alluvial flow diagrams were also made with the Raw program (https://rawgraphs.io/).

\section{Results}


The main results are shown below.

3.1. Research patterns in psychology publications

The publications in the "Psychology" area of Web of Science were examined, and 1.797.533 documents were identified. The earliest publications in WoS dated back to 1900, though it was not until the mid-1950s that production figures became significant. Growth accelerated in 2000; half of the documents published on psychology appeared in or after the year 2000. The main country responsible for publications is the USA, with $45 \%$ of the psychology documents, followed by England, Canada, Germany and Australia with proportions ranging between $4 \%$ and $8 \%$. Spain occupies eighth position with $1.7 \%$ of publications the world over. The leading disciplines in production are "Psychology Multidisciplinary" (with $25 \%$ of the publications), "Psychology General" (with $24 \%$ ) and "Psychology Clinical" (17\%). "Psychology Social" accounts for $8 \%$ of the "Psychology" publications (Figure 1).
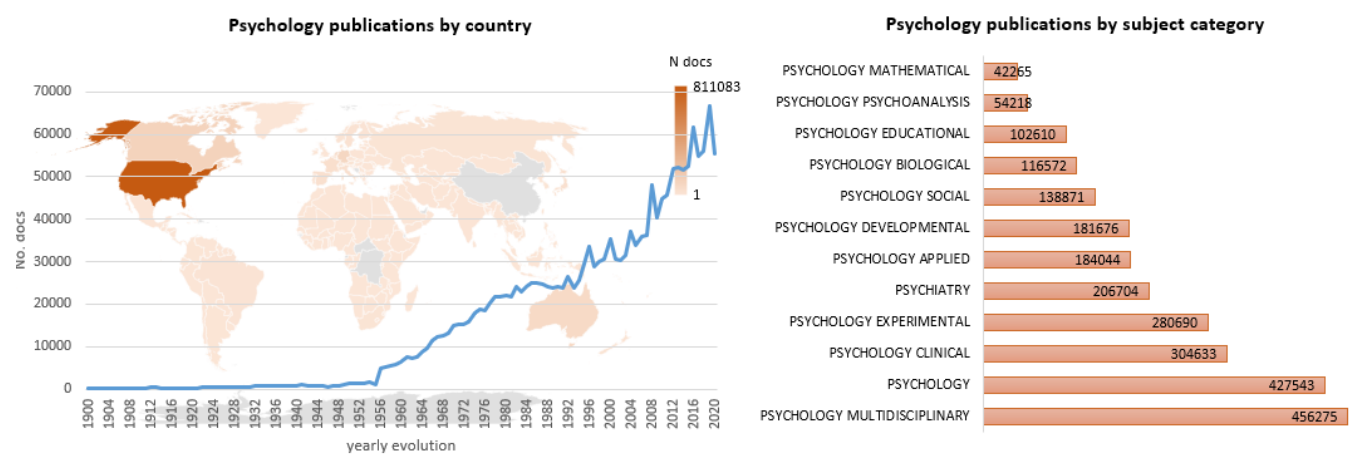

Figure 1. Characteristics of scientific publications on psychology (Web of Science 19002020)

3.2. Research patterns in Spanish social psychology publications

Analysis of the social psychology production shows that the earliest publications indexed in WoS date from the 1980s. Production growth has been steady. Here, too, half of the documents date from 2000 or later. The USA is the leading producer, and Spain holds ninth place with $1.2 \%$ of world production. Figure 2 shows the annual development of world production (blue line) and Spanish production (yellow line). 


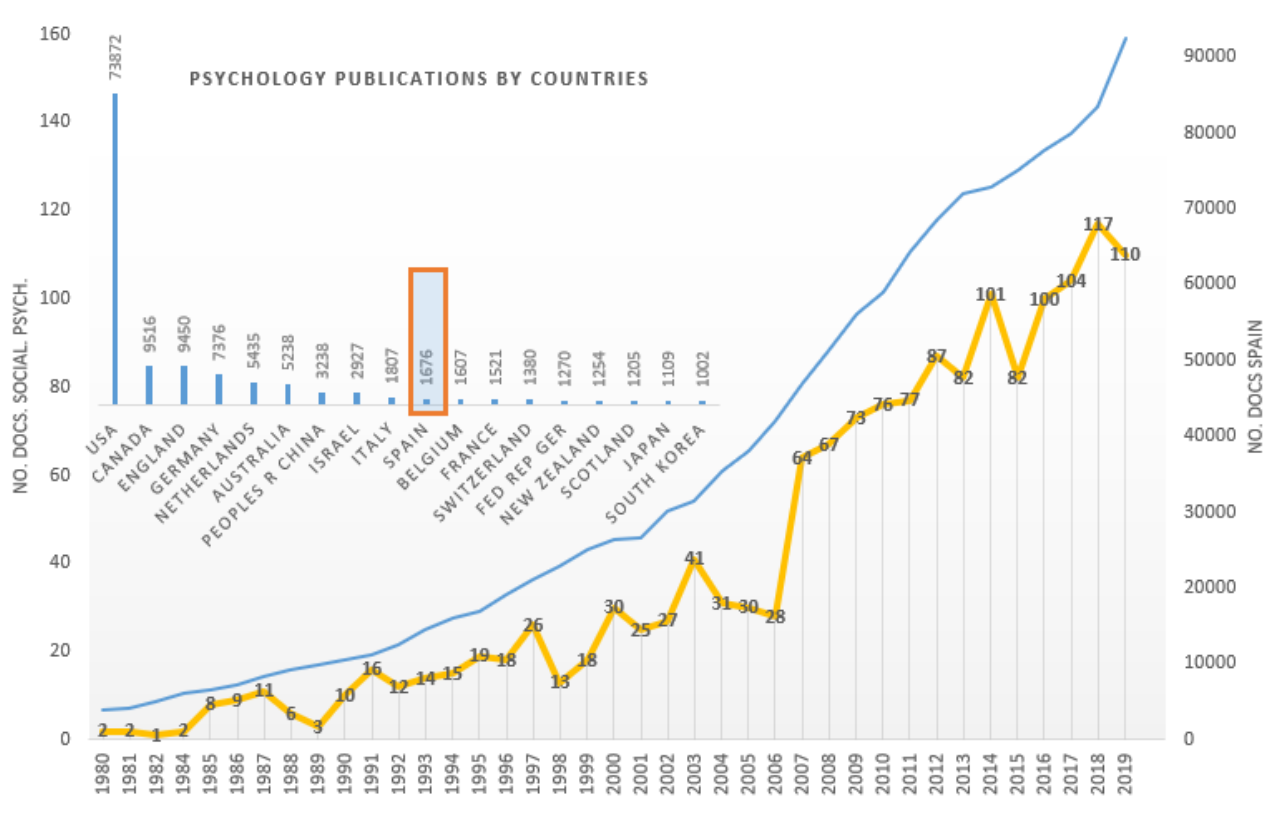

Figure 2. Characteristics of scientific publications on social psychology (Web of Science 1980-2020)

Spanish institutions, primarily public universities, participated in 1632 documents. The Autónoma University of Madrid heads the list, with $12 \%$, followed by the University of Granada and the University of Valencia. Table 1 lists the institutions that participated in more than 20 documents (Table 1).

Table 1. Spanish institutions with social psychology publications (>20 documents)

\begin{tabular}{|l|r|r|}
\hline Institution & $\begin{array}{l}\text { No } \\
\text { docs }\end{array}$ & \multicolumn{1}{l|}{$\%$} \\
\hline $\begin{array}{l}\text { Autónoma University } \\
\text { of Madrid }\end{array}$ & 203 & 12.44 \\
\hline University of Granada & 166 & 10.17 \\
\hline University of Valencia & 129 & 7.90 \\
\hline $\begin{array}{l}\text { Complutensian } \\
\text { University of Madrid }\end{array}$ & 124 & 7.60 \\
\hline $\begin{array}{l}\text { National Distance } \\
\text { Education University }\end{array}$ & 123 & 7.54 \\
\hline $\begin{array}{l}\text { University of the } \\
\text { Basque Country }\end{array}$ & 122 & 7.48 \\
\hline University of Barcelona & 110 & 6.74 \\
\hline $\begin{array}{l}\text { Autónoma University } \\
\text { of Barcelona }\end{array}$ & 99 & 6.07 \\
\hline Jaume I University & 71 & 4.35 \\
\hline University of Lleida & 53 & 3.25 \\
\hline University of Malaga & 50 & 3.06 \\
\hline $\begin{array}{l}\text { University of La } \\
\text { Laguna }\end{array}$ & 48 & 2.94 \\
\hline $\begin{array}{l}\text { University of Santiago } \\
\text { de Compostela }\end{array}$ & 48 & 2.94 \\
\hline $\begin{array}{l}\text { Rovira I Virgili } \\
\text { University }\end{array}$ & 44 & 2.70 \\
\hline
\end{tabular}

\begin{tabular}{|l|r|r|}
\hline Institution & $\begin{array}{l}\text { No } \\
\text { docs }\end{array}$ & \multicolumn{1}{l|}{$\%$} \\
\hline $\begin{array}{l}\text { Pompeu Fabra } \\
\text { University }\end{array}$ & 41 & 2.51 \\
\hline $\begin{array}{l}\text { University of } \\
\text { Salamanca }\end{array}$ & 41 & 2.51 \\
\hline University of Almeria & 39 & 2.39 \\
\hline University of Sevilla & 39 & 2.39 \\
\hline Deusto University & 36 & 2.21 \\
\hline $\begin{array}{l}\text { Ciber Centro de } \\
\text { Investigación } \\
\text { Biomedica en Red }\end{array}$ & 35 & 2.14 \\
\hline University of Jaen & 30 & 1.84 \\
\hline University of Murcia & 30 & 1.84 \\
\hline University of Córdoba & 26 & 1.59 \\
\hline University of Navarra & 25 & 1.53 \\
\hline $\begin{array}{l}\text { Miguel Hernandez } \\
\text { University of Elche }\end{array}$ & 24 & 1.47 \\
\hline $\begin{array}{l}\text { University of Castilla } \\
\text { La Mancha }\end{array}$ & 23 & 1.41 \\
\hline ICREA & 22 & 1.35 \\
\hline University of Oviedo & 22 & 1.35 \\
\hline University of Zaragoza & 22 & 1.35 \\
\hline CIBERSAM & 21 & 1.29 \\
\hline
\end{tabular}

Among the journals publishing documents signed by Spanish institutions, Personality and Individual Differences contains nearly one fourth of Spain's production, followed by 
Revista de Psicología Social with 14 \%. Figure 3 lists the social psychology journals that have published more than 10 Spanish documents on social psychology.

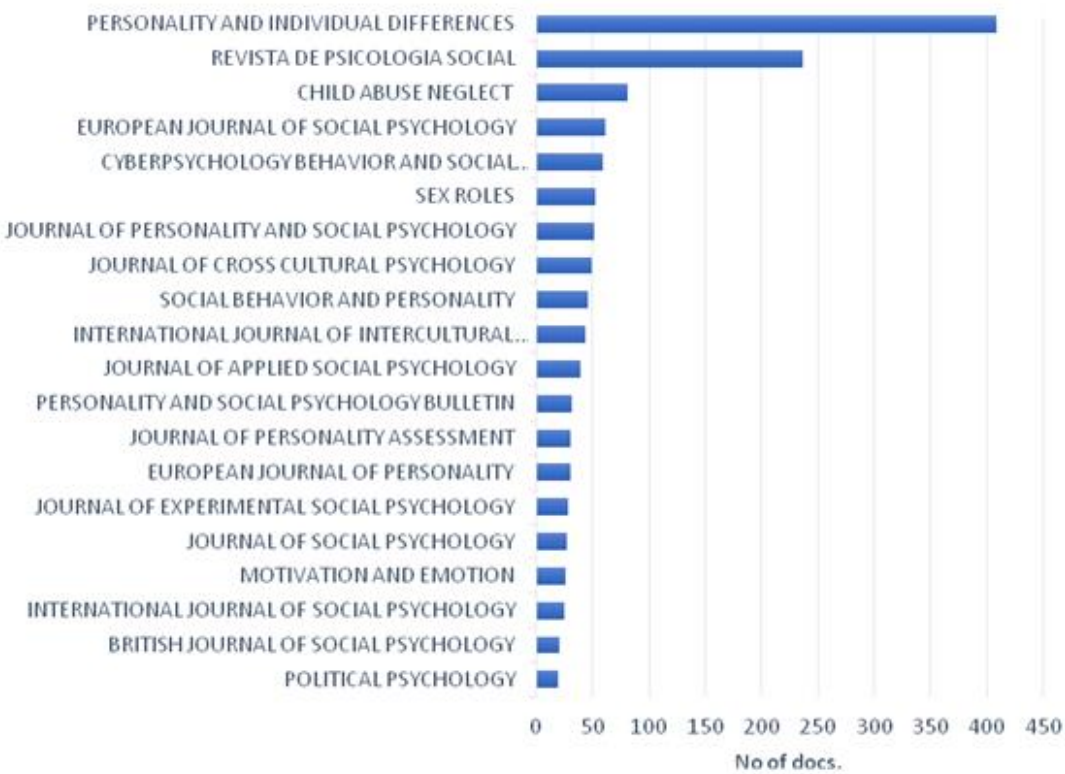

Figure 3. Most productive journals in Spanish social psychology publications (Web of Science 1980-2020)

3.2. Thematic content of Spanish social psychology publications

For a deeper analysis of publication content, the first step was to identify journal affiliation. While all the publications were classified in the WoS category of "Social Psychology", because of multi-class classification, additional areas can be identified to which the documents also pertain. Figure 4 presents a thematic network showing social psychology's relationships with other disciplines that are also addressed in the journals at issue. Node size indicates the volume of documents assigned to each theme. The variety of disciplines in the network attests to the wide thematic spectrum that social psychology covers (Figure 4).
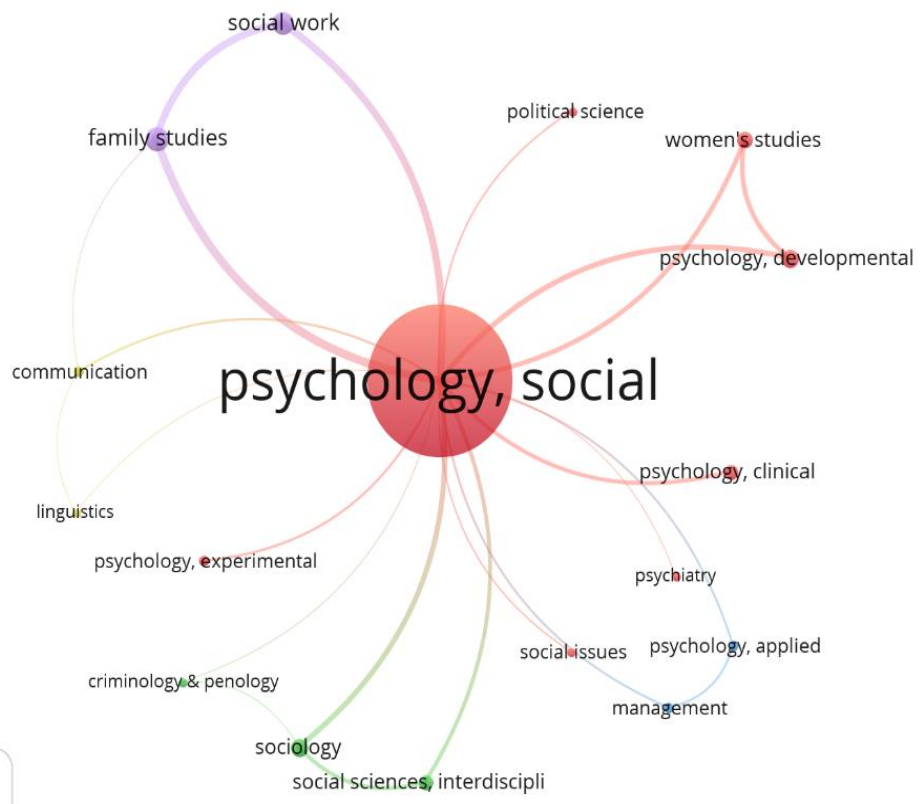
Figure 4. Disciplinary relationship through thematic classification of social psychology journals. (WoS 1980-2020)

Keywords are another important content-related aspect. Keyword analysis was used to identify primary research topics. Figure 5 shows a cluster analysis based on keyword co-occurrence to detect the main thematic clusters (each identified with a colour). These clusters include "attitudes", "persuasion", "individual differences", "personality", "women and gender", "health" and "adolescents". The relationships between terms can also be observed by the edges. Node size is proportional to the number of documents associated with each keyword.

Attitudes, considered the predecessor and predictor of social conduct, have been a mainstay among social psychology research topics from the discipline's start. It makes sense for attitudes and other related topics to occupy an important space (red colour) on the thematic cluster map in Figure 5. By the size of its node, attitudes can be readily seen to be one of the topics with the most associated documents; there are also documents addressing the study of concepts closely related with attitudes, such as beliefs, emotions, values and behaviour possibly related with certain attitudes, e.g., altruism. The "attitudes" thematic cluster also contains attitudes and relationships between social groups, outgroups and associated processes, such as stereotypes, prejudices and discriminatory conduct, group inclusion, group integration, group conflict and more recent topics in social psychology research, like identity fusion. Some documents in the cluster refer to attitudes toward specific groups (e.g., immigrants) and associated topics, like ethnic identity, the emotional climate and social emotions like shame. Documents referring to research into the self also figure prominently in the "attitudes" cluster, since the self is an important research topic in social psychology. The intense interest social psychologists displayed in COVID-19 in 2020 is also reflected in the "attitudes" area. Lastly, some documents refer to the theoretical models used as a reference in various research projects concerning attitudes.

The "attitudes" node is related with nodes of documents concerning the processes involved in change of attitude or persuasion (yellow cluster); these nodes contain documents related with the processes affecting attitudes: cognitive processes, metacognitive processes, the sort of information available, attitude characteristics such as attitude strength, accessibility, ambivalence, personality variables like self-esteem and mood, plus documents related with some of the possible measurements of attitude, like implicit association tests. The documents associated with attitudes are linked with an empirical cluster of documents referring to the area of cognition and emotion (social cognition) (yellow colour), a major area of social psychology research since the 1980s, which encompasses the study of cognitive and emotional processes that can help understand, explain and predict social conduct (information, accessibility, biases, priming, social judgment, etc.).

The "attitudes" cluster's edges are related with the "women and gender" cluster (light blue colour). This cluster identifies documents about the various kinds of sexist attitudes (benevolent sexism, ambivalent sexism, hostile sexism), inequality between women and men and discrimination against women.

Some of the documents on cognitive and emotional processes that have been of interest to social psychologists to explain social conduct show a relationship with documents addressing individual differences (orange colour); and the nodes referring to intelligence or other cognitive competences (e.g., "comprehension"), achievement, emotions and emotional competences are easily identified. Complementing this, the documents on individual differences overlap the clusters of research documents about personality variables or styles, temperament, skills, etcetera.

The thematic cluster dealing with personality (dark blue color) is another of the major thematic blocks making up the map. The "personality" node documents include three 
groups: documents referring to personality variables (extraversion, impulsivity, sensation seeking, etc.), documents referring to personality measurement scales (e.g., the big five scale) and studies designing, validating and analysing the psychometric properties of personality scales and/or adapting scales to measure personality variables in the Spanish context.

The thematic cluster of health publications (purple color) is another major research area in social psychology. It includes documents bearing a significant relationship with health issues like stress, life satisfaction and emotional adjustment. This cluster has strong relationships with the "attitude" cluster, the cluster of cognitive and emotional processes and the "personality" cluster, and with health in various environments, such as the work environment.

Lastly, adolescents and their behaviour (green cluster) have received and still receive a great deal of attention from studies published in social psychology journals. In the "adolescents" cluster we see document clusters referring to adjustment or social adaptation, risky behaviour, aggressive behaviour, mental health, substance abuse and violence, along with clusters referring to abuse, maltreatment, exposure to violence (domestic or institutional), harassment, cyberbullying, relationships with parents, etcetera.

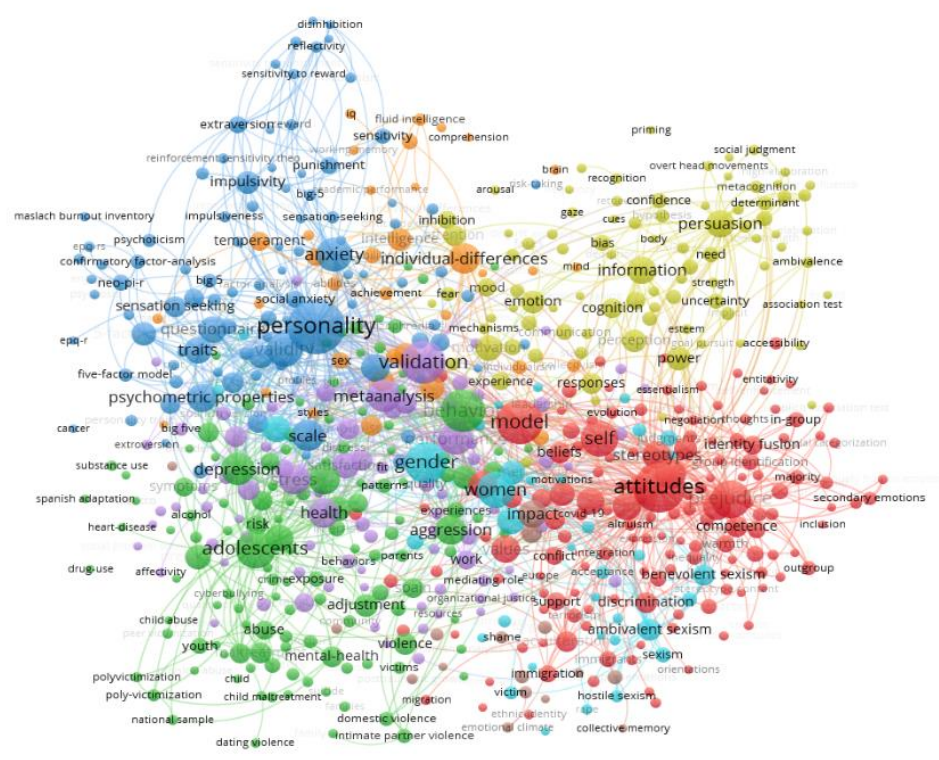

Figure 5. Cluster analysis through co-occurrence of keywords in Spanish social psychology publications (WoS 1980-2020)

\subsection{Contribution to SDGs}

The documents were subjected to content review for a more in-depth analysis of social psychology's contribution to the SDGs. The first step was to apply the OSDG tool, which associated the highest percentage of documents with SDG 3 (good health and wellbeing). The results were validated through an in-depth content analysis. Since a single document may deal with multiple topics, there are cases of publications assigned to more than one SDG. The results in Table 2 show the percentage of documents related most strongly with each of the SDGs. SDG 3 and SDG 5 are the goals with the largest numbers of documents.

Table 2. Assignment of social psychology publications to SDGs 


\begin{tabular}{|c|c|c|}
\hline SDG & Frequency & \% (n=1632) \\
\hline SDG_3 & 390 & 23.90 \\
\hline SDG_5 & 78 & 4.78 \\
\hline SDG_16 & 65 & 3.98 \\
\hline SDG_4 & 30 & 1.84 \\
\hline SDG_9 & 24 & 1.47 \\
\hline SDG_8 & 18 & 1.10 \\
\hline SDG_11 & 6 & 0.37 \\
\hline SDG_1 & 4 & 0.25 \\
\hline SDG_10 & 3 & 0.18 \\
\hline SDG_12 & 3 & 0.18 \\
\hline Unassigned & 1086 & 66.54 \\
\hline Total & 1632 & 66.54 \\
\hline
\end{tabular}

After the publications were assigned to the SDGs, the targets associated with each SDG (https://www.un.org/sustainabledevelopment/es/health/) were identified with a view to establishing more-precise relationships between document content and SDGs.

In accordance with the hypothesis, the documents associated with SDG 3 generally describe studies oriented toward analysing variables and processes affecting health (physical or mental) and psychological well-being. One of the targets set in SDG 3 is to prevent, provide treatment for and promote mental health and well-being. The documents report diverse factors that can affect the achievement of this target. One such factor is harmful social relationships. Harmful social relationships, whether in the family, at work or in other social spheres, including mistreatment, abuse (be it physical, psychological or sexual) and abandonment, have a negative affect on the physical and mental health of caught up in them. The bibliography we analysed also shows that children and adolescents are especially vulnerable in harmful social relationships, making it difficult to reach the SDG 3 target of caring for and protecting children. In this sense, the documents we reviewed make it clear that victimization or poly-victimization (sexual, electronic, etc.) impairs the mental health (depression, anxiety) of adolescents interned in centres, as mentioned, for example, by Segura et al. [11]; sexual abuse and sexual victimization particularly generate emotional disorders and anxiety in women [12] and adolescents [13]. Adolescents' mental health is also impaired by emotional abuse from parents within the family and from peers [14]. In general, parenting style and peer attachment predict emotional instability in late childhood and early adolescence [15]. Diverse studies show that the various kinds of abuse and abandonment are associated with poly-drug use in adolescents [16]. Other papers trace a relationship between child abuse and depressive disorders and attention problems in children [17].

Furthermore, another subgroup of documents reveals that certain personality variables (neuroticism, introversion, etc.) and coping styles bear a negative association with mental health $[18,19]$, alcohol consumption $[20,21]$ or physical health, as in the case of type-A personalities and high blood pressure [22].

Other studies provide evidence that the family environment can be a protective factor in mental health. A positive relationship exists between well-being and family identity or a positive feeling of belonging [23], and between well-being at work and at home [24]. In addition, well-being is associated with competence to manage emotions or emotional intelligence in different environments of daily life [25]. For example, dissatisfaction in the work environment generates emotional distress (depression, anxiety, stress) and even serious mental health problems [26], while leadership capability is associated with well- 
being in the work environment [27]. In social relations, the feeling of cultural integration is associated positively with well-being [28]. Some of the papers analysed also mention that personal well-being is associated with, among many other factors, volunteering [29] and a positive body self-image [30].

Other SDG 3 targets that some of the reviewed research documents are associated with have to do with preventing and treating the use of addictive substances like drugs, alcohol and tobacco. The publications show that gender roles number among the psychosocial factors associated with drug and alcohol consumption: role acceptance favours alcohol consumption in the case of the masculine role and provides protection from alcohol consumption in the case of feminine roles [31]. Tobacco consumption, a behaviour that affects health negatively the world over, is associated with emotional processes, personality variables [32], thrill seeking [33] and anxiety [34], among other factors.

In the social psychology publications analysed, the contents related with SDG 5 hold second place in terms of document volume. The targets set in the 2030 Agenda for SDG 5 (https://www.un.org/sustainabledevelopment/es/gender-equality/) aim at ending discrimination against women and girls worldwide and eliminating all forms of violence against women in the public and private spheres. Some of the documents show that the sexual roles society assigns to women number among the factors that form a barrier to achieving this target and that women's adoption of such roles places constraints on their life and their personal and career development.

These learned sexual roles are expressed in different spheres. In the case of the career sphere, they may lead to greater accommodation and less competitiveness in the case of women, which does not help reduce inequalities [35]. Some of the studies alert that political leaders, the media and educators, among others, should be aware of how women's conformity with traditional gender stereotypes can also lead women to negative consequences similar to other hostile forms of stranger harassment [36]. The roles women accept can affect how women manage emotions such as guilt in conflict situations. Some publications show that women with high dependency feel guiltier than women with low dependency in high-conflict situations [37]. Some documents [38] provide an overview of acceptability and public attitudes that support the use of gender violence and focus on the effect of gender and gender role attitudes. The data review shows that Spanish society as a whole considers intimate partner violence against women as a social problem and rejects it, but there are still some violence-supportive attitudes, such as victim blaming, and there is a gender gap in the consideration of gender violence as well.

Some of the publications [39] address how the intergenerational transmission of benevolent sexist beliefs from mothers to adolescent daughters negatively influences daughters' traditional goals, academic goals (i.e., getting an academic degree) and academic performance, perpetuating gender inequalities. Psychosocial research also confirms the presence of sexist attitudes in society that can be used to legitimize and maintain gender violence and foster a climate of social permissiveness towards sexual violence towards women [40]. Lastly, gender stereotypes are found to persist in the educational sphere, as some documents show with respect to physical education [41] and physical education textbooks [42], where there is a noticeable imbalance between male and female representation in which the male model is clearly predominant. In addition, textbook images portray males and females in stereotypical roles and depict certain activities or sports as more appropriate for one gender or the other.

Some of the research reports how the presence of gender stereotypes in daily life impedes the achievement of SDG 5's targets, because they constrain the role women play in society. Spanish national online newspapers mantain the underrepresentation, stereotyping and discrimination of women in web news, thereby reinforcing gender inequality [43]. In a review of Spanish newspaper articles and advertisements [44], men were found to be more commonly featured in articles, photographs and advertisements than women and much more frequently depicted as soldiers, athletes or high-ranking businesspersons than 
women. Furthermore, the reporters writing the articles were more likely to be men than women. In addition, men were more likely to be cited as sources than women. The equivalent is found to happen in radio advertisements [45]: there is a strong tendency to employ male voices more often than female voices in the belief that male voices sound more convincing. Accordingly, the supremacy of the male voice over the female voice in radio advertising and the repeated association between voices and product types is more based on tradition than on the real effectiveness of the advertisements.

\section{Discussion and conclusions}

The bibliometric study shows that social psychology as a discipline has made important strides in terms of publications; publication numbers rose considerably starting in 2000. This increase in international publication speaks as to the activity patterns of Spanish scientists, who have accepted publication in indexed journals as one of the main channels for disseminating research results, as per the guidelines set by research, development and innovation evaluation authorities.

In the field of psychology, Spain holds eighth place in the world in terms of Web of Science publication numbers. This is a better position than anticipated, since the country is tenth by overall WoS production in all disciplines [46]. Social psychology accounts for $8 \%$ of all Spanish production in psychology, and universities (particularly the Autonomous University of Madrid) are the main producers. Personality and Individual Differences is the journal with the highest volume of social psychology documents. Document cluster analysis shows that there are six main thematic groups: attitudes, persuasion, individual differences, personality variables, women and gender and adolescents.

Most of the problems and challenges that Agenda 2030 [2] has taken on already existed before they were formally embodied as the 17 SDGs in 2015, and some of them those that have to do with personal health and well-being- are especially close to the objectives of social psychology. The Agenda was created to make these problems and challenges visible and to combine the efforts and resources of many organisations and social agents to correct them. The WHO's call to broad social participation in the health sphere is very clear. In this sense, and in line with the WHO's mission to improve human wellbeing and health, social psychology could be expected to have made significant scientific contributions to improve human relations and social contexts that favour well-being, in the direction indicated by the SDG targets.

Keyword-based document content analysis draws a map where we can read the diversity of the topics social psychology addresses, discerning the major areas of research and seeing how intensely each area has been researched in terms of the number of documents addressing that area. A second analysis shows that, in accordance with our hypothesis, the research topics social psychology deals with are primarily related with SDG 3 (good health and well-being). A smaller number of documents is associated with SDG 5. One conclusion drawn from our review is that, through its prolific research, social psychology has helped improve knowledge about the cognitive, emotional and contextual processes that can influence the kinds of social conduct that ought to be ensured or modified if we are to reach the targets set in SDG 3 and SDG 5.

The second conclusion, drawn from the scanty $2 \%$ of intervention studies published in WoS, is that social psychology has made only a limited contribution to research enabling us to learn to generate the kind of behaviour or social contexts required to reach the SDG targets, while at the same time remedying the environmental, economic and social blunders that irresponsible human behaviour has caused. For decades social psychology has been criticized for making only puny contributions to solving real social problems. Other reviews of the scope of social psychology have pointed to social psychology's lack of real impact on the treatment of social problems [47-49] considering that social psychology research has not led to any substantive progress in human well-being or human 
relations [50]. In short, social psychology is still being called to task for decades of failure to produce proactive intervention in favour of well-being and health [3,51-53].

At all events, Agenda 2030 offers a framework of action in which the discipline is still in time to apply its hard-won decades of knowledge to the problems the Agenda showcases and to help face the social challenges of now and the future [2]. While continuing to strive to push research publications into ever-better positions in terms of bibliometric impact, researchers, as social psychologists, ought to take advantage of the opportunity to pit their skills against the social challenges and problems yet to be resolved, and in this endeavour they should apply the knowledge, methods and tools that social psychology has created. For all these reasons, we feel that this study is a contribution to the realm of social psychology, because it provides orientation in tracing the activity patterns of social psychology and its relationship with topics of great social significance, such as those proposed in the 2030 Agenda. However, we are aware that all studies have certain limitations. In this sense, while analysis of the scientific production published in international journals makes a major share of research results visible (those belonging to the main scientific current), it neglects other documents that may be equally significant within the discipline. As mentioned before, the culture of evaluation currently pervading the academic community has led to the adoption of practices that favour the publication of findings in journals of a certain type (journals indexed in international databases), while other kinds of findings (in this case, the findings of interventions aimed at solving specific social problems) do not seem to be as easily accommodated in international publications. It is important to draw attention to this fact, because, apart from being a methodological constraint, it may become an increasingly accentuated practice, drawing the limelight away from the kinds of studies that, by definition, ought to be the core of the practice of social psychology.

Author Contributions: Conceptualization: FS, MLL, DDF; methodology: FS, MML, DDF; data collection: DDF; validation: FS, MML; formal analysis: FL, MLL, DDF; visualization: DDF; writingoriginal draft preparation: FS, MML, DDF; writing - review and editing: $A B$.

Funding: Please add: The results presented were obtained within the framework of the project "Towards the consolidation of inclusive cities, a challenge for Madrid" (H2019/Hum-5744), funded by the Community of Madrid.

Acknowledgments: The authors wish to thank Nuria Baustista-Puig for their assisting with OSDG tool).

Conflicts of Interest: "The authors declare no conflict of interest."

\section{References}

1. WHO (2021). Voice, agency, empowerment - handbook on social participation for universal health coverage. Geneva: World Health Organization. Licence: CC BY-NC-SA 3.0 IGO.

2. UN (2015). Transforming Our World: The 2030 Agenda for Sustainable Development. NY: United Nations. http://bit.ly/TransformAgendaSDG-pdf.

3. Miller, G. (1969). Psychology as a Means to Promoting Social Welfare. American Psychologist, 24, 1063-1075. https://doi.org/10.1037/h0028988

4. Keyes, C. (1998). Social well-being. Social Psychology Quarterly, 61,121-140. https://doi.org/10.2307/2787065

5. Blanco, A., \& Díaz, D. (2005). El bienestar social: su concepto y medición. Psicothema, 17(4), 582-589 https://www.redalyc.org/articulo.oa?id=72717407

6. Blanco, A. (1980). La psicología social: Desorientación y aplicación a la realidad española. REIS, 12, 159194. https://doi.org/10.2307/40182884

7. Aronson, E. (1975). Introducción a la psicología social. Madrid: Alianza

8. Vygotski, L.S. (1991). El significado histórico de la crisis en psicología. In L.S. Vygotski, Obras escogidas, Vol. I (pp. 259-413). Madrid: Visor Aprendizaje.

9. Lewin, K. (1988). La teoría del campo en la ciencia social. Barcelona: Paidós. 
10. Carpintero, H. (2017). La psicología aplicada como modelo teórico. In Academia de Psicología de España, Psicología para un mundo sostenible. (pp. 13-33). Madrid: Pirámide.

11. Segura, A., Pereda, N., Guilera, G., \& Abad, J. (2016). Poly-victimization and psychopathology among Spanish adolescents in residential care. Child Abuse $\mathcal{E}$ Neglect, 55, 40-51. https://doi.org/10.1016/j.chiabu.2016.03.009

12. Cantón-Cortes, D., Cantón, J., \& Cortes, M.R. (2016). Emotional security in the family system and psychological distress in female survivors of child sexual abuse. Child Abuse $\mathcal{E}$ Neglect, 51, 54-63. https://doi.org/10.1016/j.chiabu.2015.11.005

13. Pérez-González, A., Guilera, G., Pereda, N., \& Jarne, A. (2017). Protective factors promoting resilience in the relation between child sexual victimization and internalizing and externalizing symptoms. Child Abuse $\mathcal{E}$ Neglect, 72, 393-40. https://doi.org/10.1016/j.chiabu.2017.09.006

14. Calvete, E. (2014). Emotional abuse as a predictor of early maladaptive schemas in adolescents: Contributions to the development of depressive and social anxiety symptoms. Child Abuse E Neglect, 38 (4), $735-$ 746. https://doi.org/10.1016/j.chiabu.2013.10.014

15. Llorca-Mestre, A., Samper-Garcia, P., Malonda-Vidal, E., \& Cortes-Tomas, MT. (2017). Parenting style and peer attachment as predictors of emotional instability in children. Social Behavior and Personality: an international journal, 45(4), 677-694. https://doi.org/10.2224/sbp.5363

16. Álvarez-Alonso, M. J., Jurado-Barba, R., Martinez-Martin, N., Espin-Jaime, J.C., Bolaños-Porrero, C., ... Rubio, G. (2016). Association between maltreatment and polydrug use among adolescents. Child Abuse $\mathcal{E}$ Neglect, 51, 379-389. https://doi.org/10.1016/j.chiabu.2015.07.014

17. Bertó, C., Ferrin, M., Barberá, M., Livianos, L., Rojo, L., \& García-Blanco, A. (2017). Abnormal emotional processing in maltreated children diagnosed of Complex Posttraumatic Stress Disorder. Child Abuse $\mathcal{E}$ Neglect, 73, 42-50. https://doi.org/10.1016/j.chiabu.2017.09.020

18. Moret-Tatay, C., Beneyto-Arrojo, M.J., Laborde-Bois, S., Martínez-Rubio, D., \& Senent-Capuz, N. (2016). Gender, Coping, and Mental Health: a Bayesian Network Model Analysis. Social Behavior and Personality: an international journal, 44(5), 827-835. https://doi.org/10.2224/sbp.2016.44.5.827

19. Etkin, P., Mezquita, L., López-Fernández, F. J., Ortet, G., \& Ibáñez, M. I. (2020). Five factor model of personality and structure of psychopathological symptoms in adolescents. Personality and Individual Differences,163, https://doi.org/10.1016/j.paid.2020.110063

20. Ibáñez, M. I., Moya, J., Villa, H., Mezquita, L., Ruipérez, M. A., \& Ortet, G. (2010). Basic personality dimensions and alcohol consumption in young adults. Personality and Individual Differences, 48(2), 171-176. https://doi.org/10.1016/j.paid.2009.09.017

21. Aluja, A., Lucas, I., Blanch, A., \& Blanco, E. (2019). Personality and disinhibitory psychopathology in alcohol consumption: A study from the biological-factorial personality models of Eysenck, Gray and Zuckerman. Personality and Individual Differences, 142, 159-165. https://doi.org/10.1016/j.paid.2019.01.030

22. Sanz, J., García-Vera, M.P., Magán, I., Espinosa, R., \& Fortún, M. (2007). Differences in personality between sustained hypertension, isolated clinic hypertension and normotension. European Journal of Personality, 21(2), 209-224. https://doi.org/10.1002/per.605

23. Herrera, M., Sani, F., \& Bowe, M. (2011). Perceived family continuity: Implications for family identification and psychological well-being. Revista de Psicología Social, 26(3), $387-399$. https://doi.org/10.1174/021347411797361275

24. Hall, D. T., Lee, M. D., Kossek, E.E., \& Las Heras, M. (2012). Pursuing Career Success while Sustaining Personal and Family Well-Being: A Study of Reduced-Load Professionals over Time. Journal of Social Issues, 68(4). https://doi.org/10.1111/j.1540-4560.2012.01774.x

25. Extremera, N., \& Rey, L. (2016). Ability emotional intelligence and life satisfaction: Positive and negative affect as mediators. Personality and Individual Differences, 102, 98-101. https://doi.org/10.1016/j.paid.2016.06.051

26. Extremera, N., Mérida-López, S., Quintana-Orts, C., \& Rey, L. (2020). On the association between job dissatisfaction and employee's mental health problems: Does emotional regulation ability buffer the link?. Personality and Individual Differences, 155. https://doi.org/10.1016/j.paid.2019. 109710

27. Espinoza-Parra, S., Molero, F., \& Fuster, M. J. (2015) Transformational leadership and job satisfaction of police officers (carabineros) in Chile: the mediating effects of group identification and work engagement. International Journal of Social Psychology, 30(3), 439-467. https://doi.org/10.1080/02134748.2015.1065087 
28. Ferrari, L., Manzi, C., Benet-Martinez, V. \& Rosnati, R. (2019). Social and Family Factors Related to Intercountry Adoptees and Immigrants' Bicultural Identity Integration. Journal of Cross-Cultural Psychology, 50(6), 789-805. https://doi.org/10.1177/0022022119850339

29. Vecina, M. L., \& Chacón, F. (2013). Volunteering and well-being: is pleasure-based rather than pressurebased prosocial motivation that which is related to positive effects? Journal of Applied Social Psychology, 43(4), 870-878. https://doi.org/10.1111/jasp.12012

30. Moreno-Domínguez, S., Servián-Franco, F., Reyes del Paso, G., \& Cepeda-Benito, A (2019). Images of Thin and Plus-Size Models Produce Opposite Effects on Women's Body Image, Body Dissatisfaction, and Anxiety. Sex Roles, 80, 607-616. http://doir.org/10.1007/s11199-018-0951-3.

31. Zimmermann, F., Sieverding, M., \& Müller, S. M. (2011). Gender-related traits as predictors of alcohol use in male German and Spanish university students. Sex Roles, 64(5), $394-404$. https://doi.org/110.1007/s11199-010-9897-9

32. Del Rio, E.F., López-Durán, A., Rodríguez-Cano, R., Martínez, U., Martínez-Vispo, C., \& Becoña, E. (2015). Facets of the NEO-PI-R and smoking cessation. Personality and Individual Differences, 80, 41-45. https://doi.org/110.1016/j.paid.2015.02.030

33. Fernández-Artamendi, S., Martínez-Loredo, V., Fernández-Hermida, J. R. \& Carballo-Crespo, J. L. (2016). The Impulsive Sensation Seeking (ImpSS): Psychometric properties and predictive validity regarding substance use with Spanish adolescents. Personality and Individual Differences, 90, 163-168. https://doi.org/10.1016/j.paid.2015.11.003.

34. Becoña, E., Vázquez, F. L., \& Míguez, M. D. (2002). Smoking cessation and anxiety in a clinical sample. Personality and Individual Differences, 328(3), 489-494. https://doi.org/10.1016/S0191-8869(01)00050-2

35. Elgoibar, P., Munduate, L., Medina, F. J., \& Euwema, M. C. (2014). Do women accommodate more than men? Gender differences in perceived social support and negotiation behavior by Spanish and Dutch worker representatives. Sex Roles: A Journal of Research, 70(11-12), 538-553. https://doi.org/10.1007/s11199014-0378-4

36. Moya-Garofano, A., Moya, M., Megías, J.L., \& Rodríguez-Bailón, R. (2020). Social Perception of Women According to their Reactions to a Stranger Harassment Situation (piropo). Sex Roles, 83, 163-178. https://doi.org/10.1007/s11199-019-01103-2

37. Valor-Segura, I., Expósito, F., Moya, M., \& López, K. (2014). Violence against women in Spain and Cuba: The same reality, two different visions. International Journal of Social Psychology, 29(1), 150179, https://doi.org/10.1080/02134748.2013.878573

38. Ferrer-Perez, V. A., \& Bosch-Fiol, E. (2014). Gender Violence as a Social Problem in Spain: Attitudes and Acceptability. Sex Roles, 70, 506-521. https://doi.org/ 10.1007/s11199-013-0322-z

39. Montañés, P., de Lemus, S., Bohner, G., Megías, J.L., Moya, M., \& García-Retamero, R. (2012). Intergenerational transmission of benevolent sexism from mothers to daughters and its relation to daughter's academic performance and goals. Sex Roles, 66, 468-478. https://doi.org/10.1007/s11199-011-0116-0

40. Durán, M., \& Rodríguez-Domínguez, C. (2020). Social perception of situations of sexual cyberviolence: The role of sexist attitudes and the victim's transgression of gender role. International Journal of Social Psychology, 35(1), 148-174. https://doi.org/10.1080/02134748.2019.1682295

41. Del Castillo-Andrés, O., Granados, S. R., González-Ramírez, T., \& Mesa, M. (2012). Gender Equity in Physical Education: The Use of Information. Sex Roles, 67, 108-121. https://doi.org/10.1007/s11199-0110103-5

42. Táboas-Pais, M. I., \& Rey-Cao, A. (2012). Gender differences in physical education textbooks in Spain: A content analysis of photographs. Sex Roles, 67(7), 389-402. https://doi.org/10.1007/s11199-012-0174-y

43. Mateos de Cabo, R., Gimeno, R., Martínez, M., \& López, L. (2014). Perpetuating Gender Inequality via the Internet? An Analysis of Women's Presence in Spanish Online Newspapers. Sex Roles, 70, 57-71 (2014). https://doi.org/10.1007/s11199-013-0331-y

44. Matud, M.P., Rodríguez, C., \& Espinosa, I. (2011). Gender in Spanish Daily Newspapers. Sex Roles, 64, 253-264. https://doi.org/10.1007/s11199-010-9874-3

45. Rodero, E., Larrea, O., \& Vázquez, M. Male and Female Voices in Commercials: Analysis of Effectiveness, Adequacy for the Product, Attention and Recall. Sex Roles, 68, 349-362. https://doi.org/10.1007/s11199-012-0247-y 
46. Clarivate Analytics (2022). InCites Essential Science Indicators. Highly Cited Threshold. Available online at: https://esi.clarivate.com/ThresholdsAction.action

47. Lewin, K. (1947). Frontiers in group dynamic: II. Channels of group life; social planning and action research. Human relations, 1 (2), 143-153 https://doi.org/10.1177/001872674700100201

48. Tajfel, H. (1981). Human groups and social categories. Cambridge: Cambridge University Press (Versión española Tajfel, H. [1984]. Grupos humanos y categorías Sociales. Barcelona: Herder).

49. Martín-Baró, I. (1983). Acción e ideologia. Psicología social desde Centroamérica. San Salvador: UCA editores.

50. Briñol, P., Blanco, A., \& de la Corte, L. (2008) Sobre la resistencia a la Psicología Social. Revista de Psicología Social, 23(1), 107-126. https://doi.org/10.1174/021347408783399507

51. Blanco, A., \& Varela, S. (2007). Los fundamentos de la intervención psicosocial. In: A. Blanco \& J. Rodríguez Marín (Eds.) Intervención psicosocial (pp-3-45). Madrid: Pearson Educación

52. Nelson, G., \& Prilleltensky, I. (Eds) (2005). Community Psychology: In Pursuit of Liberation and Well-Being. Palgrave Macmillan.

53. Yela, C. (2013) (Coord.). Psicología social de los problemas sociales. Madrid Grupo 5. 